\title{
Isolation and characterization of an Escherichia coli mutant defective in resuming growth after starvation
}

\author{
Deborah A. Siegele ${ }^{1,2}$ and Roberto Kolter ${ }^{3}$ \\ ${ }^{2}$ Department of Biology, Texas A\&M University, College Station, Texas 77843-3258 USA; ${ }^{3}$ Department of Microbiology and \\ Molecular Genetics, Harvard Medical School, Boston, Massachusetts 02115 USA
}

\begin{abstract}
To understand the mechanisms that allow the enteric bacterium Escherichia coli to make the transitions between growth and stationary phase and to maintain cell viability during starvation, we have looked for mutants defective in stationary-phase survival (a Sur ${ }^{-}$phenotype). In this paper we describe a conditional $E$. coli mutant, surB1, that grows normally and remains viable during stationary phase but is unable to exit stationary phase and resume aerobic growth at high temperature. Thus, the surB gene product is not required for cell survival per se but, rather, it is required for starved cells to reinitiate growth under restrictive conditions. Once growth has started, SurB function is no longer required. Mutant cells sense and respond to fresh medium but appear to arrest growth before the first cell division. The surB gene was mapped to 19.5 min on the $E$. coli chromosome, cloned, and sequenced. The surB gene product is predicted to be an integral membrane protein with multiple membrane-spanning regions and is homologous to the ATP-binding cassette (ABC) family of transporters, a large family of transport proteins found in both prokaryotic and eukaryotic cells. An open reading frame, designated ybjA, was found immediately upstream of $\operatorname{sur} B$ and may be in an operon with surB. The predicted ybjA gene product is also homologous to the $\mathrm{ABC}$ transporter family and SurB and YbjA may function together in a common transport pathway. Either surB or ybjA may be the same gene as $c y d C$, a gene described previously whose function is needed for the production of functional cytochrome $d$ oxidase complexes. Consistent with this prediction, surB1 mutant cells were found to lack functional cytochrome $d$ oxidase. However, the SurB- phenotype is not simply attributable to the absence of cytochrome $d$ oxidase. Thus, the surB gene product may have an additional role in the cell.
\end{abstract}

[Key Words: Stationary phase; survival; starvation; outgrowth; cytochrome oxidase; transporter]

Received Feburary 18, 1993; revised version accepted October 15, 1993.

One of the major environmental factors influencing microbial cell growth is nutrient availability, and microorganisms have evolved a variety of mechanisms that allow them to survive in environments where the nutrient supply fluctuates. In general, microorganisms do not respond to starvation by simply arresting all metabolic activity and stopping growth. Instead, they carry out starvation-induced programs that allow them to exit from the cell cycle, maintain viability during starvation, and resume growth when nutrients become available (Kjelleberg et al. 1987; Matin et al. 1989; Siegele and Kolter 1992). The life cycle of many microbes can be seen as consisting of two phases: (1) a growth phase where cells are in the cell cycle and growing at a rate partly determined by the available nutrient supply, and (2) a starvation or stationary phase where cells have left the cell cycle and growth is prevented by nutrient limitation. The transitions between these two stages involve dra-

\footnotetext{
${ }^{1}$ Corresponding author.
}

matic changes in gene expression, physiology, and cell morphology.

Some of the best-characterized responses to starvation are the starvation-induced developmental pathways that result in the formation of dormant, resistant spores (Losick et al. 1986; Malone 1990; Shimkets 1990). Even organisms that do not form such obviously differentiated cell types carry out starvation-induced programs that result in a morphologically distinct cell that is metabolically less active and also more resistant to a variety of environmental challenges (for review, see Kjelleberg et al. 1987; Matin 1991; Siegele and Kolter 1992).

To understand the mechanisms that allow the bacterium Escherichia coli to make the transitions between growth and stationary phase and to maintain cell viability during starvation, we have looked for mutants defective in stationary-phase survival (a Sur ${ }^{-}$phenotype). Mutations in several loci have been described already that affect the ability of the cell to survive in stationary phase (Reeve et al. 1984b; Mach et al. 1989; Spence et al. 1990; Tormo et al. 1990; Lange and Hengge-Aronis 1991; 
McCann et al. 1991; Li and Clarke 1992). In this paper we describe the isolation and characterization of a new mutant, surB1, with survival defects after entering stationary phase as a result of glucose starvation in minimal medium. surB1 is a conditional mutant that remains viable during starvation, but is unable to exit from stationary phase and resume aerobic growth at high temperature.

\section{Results}

Isolation of surB1

When E. coli K-12 strain ZK126 is starved for glucose in M63 minimal medium, essentially $100 \%$ of the cells in the culture remain able to form colonies after 7 days in stationary phase (Siegele et al. 1993). A mutant search was performed to identify cellular functions required for $E$. coli to survive in stationary phase under these conditions. A collection of random transposon insertion mutants was generated using the transposon mini-Tn10 kan and screened for mutants defective in surviving stationary phase as described in Materials and methods. The criterion used to define stationary-phase survival was the ability to grow and form colonies after several days in stationary phase, and we used the term $\mathrm{Sur}^{-}$to describe the phenotype of mutants identified by this screen (Tormo et al. 1990). Because the screen is based on the ability of stationary-phase cells to resume growth and form colonies on fresh medium, we expected that it could yield two classes of Sur ${ }^{-}$mutants: (1) $\mathrm{Sur}^{-} \mathrm{mu}^{-}$ tants that lose viability during stationary phase, and $(2)$ Sur $^{-}$mutants that remain viable but are unable to exit from stationary phase and resume growth after starvation.

Eight $\mathrm{Sur}^{-}$candidates were identified in a screen of 9600 insertion mutants. The mutant candidates were retested for a Sur ${ }^{-}$phenotype by measuring the number of colony-forming units (CFU) per milliliter during exponential growth and after the culture had entered stationary phase. With retesting, only one of the eight mutants was found to have a definite Sur ${ }^{-}$phenotype. This mutant was designated surB1. To test whether the mutant phenotype was attributable to the transposon insertion, phage P1vir was grown on the surB1 strain. The resulting lysate was used to transduce the wild-type strain to kanamycin resistant $\left(\mathrm{Km}^{\mathrm{R}}\right)$. All $10 \mathrm{Km}^{\mathrm{R}}$ transductants tested had the same phenotype as the original mutant strain (data not shown), indicating that the mutant phenotype is the result of this single transposon insertion.

surB1 cells remain viable, but fail to exit stationary phase at high temperature

Figure 1 shows the phenotype of the surB1 mutant. The mutant had the same doubling time in minimal glucose medium as the parental wild-type strain. When plated at $37^{\circ} \mathrm{C}$, exponential phase cultures of sur $B 1$ showed the same relationship between culture optical density (Klett
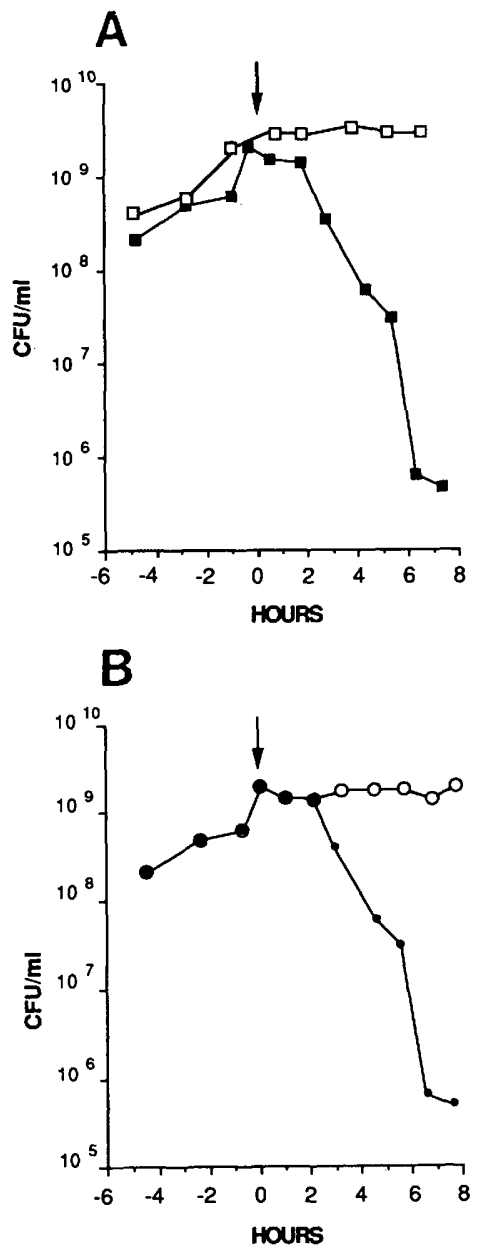

Figure 1. Phenotype of the $\operatorname{sur} B 1$ mutant. $(A)$ Cultures of ZK126 (ㅁ) and ZK126 surB1 (ㅁ) were grown in minimal glucose medium at $37^{\circ} \mathrm{C}$. At intervals samples were removed and diluted, and aliquots were plated on minimal glucose plates and incubated overnight at $37^{\circ} \mathrm{C}$. (B) A culture of ZK126 surB1 was grown in minimal glucose medium at $30^{\circ} \mathrm{C}$. At intervals, samples were removed and diluted, and aliquots were plated on minimal glucose plates that were incubated at either $30^{\circ} \mathrm{C}(O)$ or $37^{\circ} \mathrm{C}(0)$. Arrows indicate the onset of stationary phase.

units) and number of $\mathrm{CFU} / \mathrm{ml}$ as the wild-type strain. The two cultures entered stationary phase at approximately the same density and CFU/ml. In the surB1 mutant, the number of $\mathrm{CFU} / \mathrm{ml}$ began to decrease within 2-3 $\mathrm{hr}$ after entry into stationary phase (Fig. 1A). Five to $6 \mathrm{hr}$ after the cells stopped growing, the titer of the mutant culture had decreased from $10^{9}$ to $<10^{6} \mathrm{CFU} / \mathrm{ml}$. The cells that were still able to form colonies appeared to be pseudo-revertants (i.e., they were still $\mathrm{Km}^{\mathrm{R}}$, indicating that the miniTn10 kan transposon was still present but did not have the Sur ${ }^{-}$phenotype upon retesting/. Because this transposon is unable to transpose without a helper (Way et al. 1984), we infer that the $\mathrm{Km}^{\mathrm{R}}$ pseudorevertants retain the original mutation but, in addition, have acquired a second mutation that suppresses the 
$\mathrm{SurB}^{-}$phenotype and allows the cells to form colonies after entering stationary phase.

In contrast, when surB1 cells were plated at $30^{\circ} \mathrm{C}$ rather than at $37^{\circ} \mathrm{C}$, there was no decrease in the number of $\mathrm{CFU} / \mathrm{ml}$ after the culture entered stationary phase (Fig. 1B). During exponential growth surB1 cells plated with the same efficiency at both $30^{\circ} \mathrm{C}$ and $37^{\circ} \mathrm{C}$, but once the culture entered stationary phase the titer of the culture decreased if the cells were plated at $37^{\circ} \mathrm{C}$ but not if the cells were plated at $30^{\circ} \mathrm{C}$. This result indicates that the surB1 mutant remains viable in stationary phase but is unable to exit from stationary phase and resume growth at $37^{\circ} \mathrm{C}$.

To further illustrate that the surB1 mutation does not cause an overall temperature-sensitive growth phenotype, mutant cells were shifted from $30^{\circ}$ to $37^{\circ} \mathrm{C}$ during exponential growth. The data shown in Figure 2 indicate that once stationary-phase surB1 cells had resumed growth at low temperature, they could be shifted to $37^{\circ} \mathrm{C}$ with no apparent lag in their growth.

\section{Cloning and characterization of the surB gene}

The surB1 insertion mutation was mapped by cloning the fragment of chromosomal DNA containing the miniTn10 kan transposon, which was then hybridized to the Kohara ordered phage library of the $E$. coli chromosome (Kohara et al. 1984). Because the transposon does not contain any PstI sites we cloned the PstI chromosomal fragment harboring the entire transposon into the plasmid vector pUC19. All of the $\mathrm{Km}^{\mathrm{R}}$ plasmids obtained contained a common PstI fragment of $10.3 \mathrm{~kb}$, corresponding to an $8.5-\mathrm{kb}$ chromosomal PstI fragment containing the 1.8-kb transposon. One of the plasmids /designated pDS351) was used as a probe and hybridized to

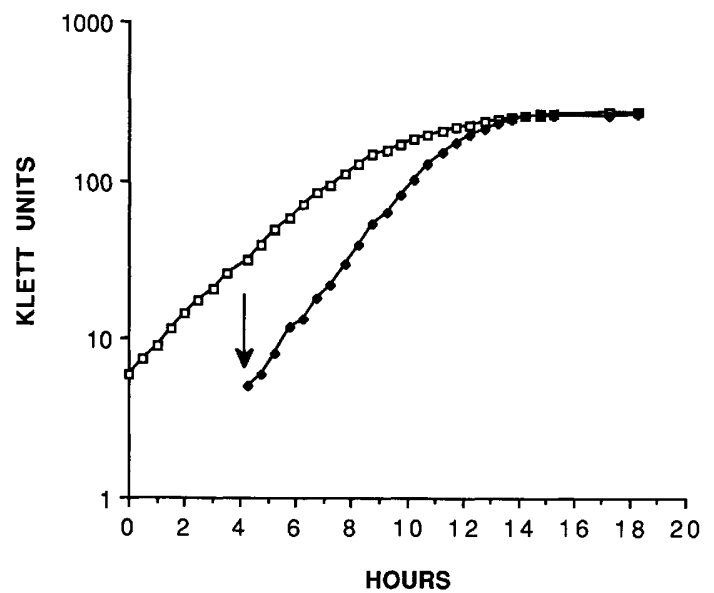

Figure 2. Temperature upshift during exponential growth. ZK126 surB1 was grown in minimal glucose medium at $30^{\circ} \mathrm{C}$. At a cell density of $\sim 10^{8} \mathrm{CFU} / \mathrm{ml}$, an aliquot of each culture was diluted into the same medium prewarmed to $37^{\circ} \mathrm{C}$. The shift is indicated by an arrow. Growth was monitored by measuring the optical density of each culture with a Klett-Summerson colorimeter. ( $\square$ ) Growth at $30^{\circ} \mathrm{C}$; (a) growth after shift to $37^{\circ} \mathrm{C}$. the Kohara ordered phage library. Three phages with overlapping inserts $[\lambda 213(1 \mathrm{H} 1), \lambda 214(1 \mathrm{~F} 10)$, and $\lambda 215$ (E6H3)] hybridized strongly to pDS351. The $E$. coli DNA in these three phages covers the region between 930 and $960 \mathrm{~kb}$ on the chromosome and is located at $19.5 \mathrm{~min}$ on the genetic map. According to the restriction map published by Kohara et al. (1984), this region of the chromosome contains an $8.5-\mathrm{kb}$ PstI fragment. The physical map of the $8.5-\mathrm{kb}$ PstI chromosomal fragment present in pDS351 matches the published restriction map for EcoRI, HindIII, KpnI, PvuII, BamHI, and EcoRV sites, except for a few minor differences in the order of restriction sites located very close to one another (Fig. 3). Restriction mapping localized the surB1::mini-Tn10 kan insertion to a $2.0-\mathrm{kb} P$ vull fragment within the $P$ stI fragment.

To identify the gene disrupted by the surB1 insertion mutation, a $2.9-\mathrm{kb}$ region was sequenced as described in Materials and methods. The sequence of this region is shown in Figure 4 . The last 346 bp of this sequence overlapped a region already sequenced (Cummings et al. 1991). Two large open reading frames (ORFs) were found. Both ORFs are oriented in the same direction with the predicted direction of transcription counterclockwise on the $E$. coli map. The surB1::mini-Tn10 kan transposon insertion disrupts the twentieth codon of a 573-codon ORF. This ORF begins with an ATG start codon, which is preceded by a potential ribosome-binding site (Gold and Stormo 1987). This ORF is referred to as the $\operatorname{sur} B$ gene. Upstream of $\operatorname{sur} B$, another potential ORF was found. This ORF is designated ybiA, to indicate a gene of unknown function between 19 and $20 \mathrm{~min}$ on the $E$. coli chromosome (Nierlich 1992). The TAA stop codon of ybjA is adjacent to and in the same frame as the proposed start codon for the sur $B$ ORF. This arrangement suggests that the two genes may be in the same operon. Because the stop and start codons are in the same frame it raises the possibility that at some frequency translational readthrough of the ybjA stop codon could occur and the two genes could be translated as a single polypeptide.

The predicted amino acid sequences of both $\operatorname{sur} B$ and $y$ bjA indicate that these proteins contain ATP-binding domains homologous to those found in the ATP-binding cassette $(\mathrm{ABC})$ family of transport proteins or traffic ATPases (Ames et al. 1990; Hyde et al. 1990). In the region containing the highly conserved ATP-binding consensus sequence, SurB is $35 \%$ identical over 218 residues to the mouse P-glycoprotein Mdr2. YbjA is $41 \%$ identical over 184 amino acids to the same protein. This level of sequence similarity is comparable with that observed for any two members of the family. The highly conserved ATP-binding sequences shared by SurB, YbjA, and other members of the $A B C$ family are indicated in Figure 4.

Hydropathy analysis of the SurB amino acid sequence predicts that SurB is an integral membrane protein (Fig. 5). There are six potential membrane-spanning regions, indicated by boxes in Figure 4. The distribution of charged amino acids indicates that the soluble, hydrophilic regions will be in the cytoplasm (Traxler et al. 1993). Thus, SurB is predicted to have the same structure 


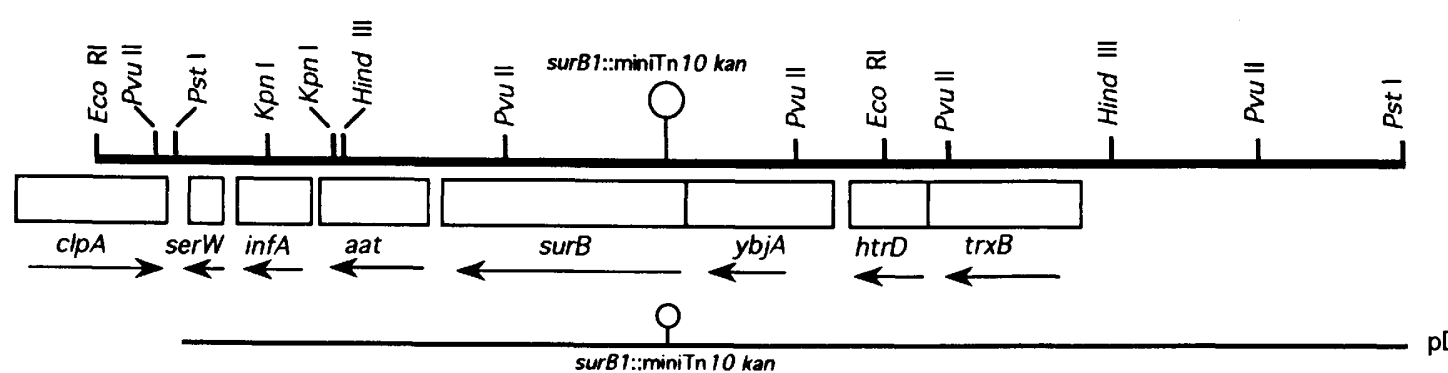

pDS351

pDS71

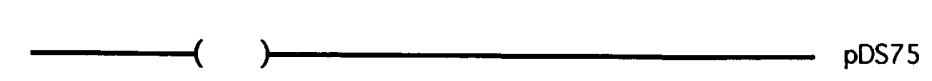

Figure 3. Physical and genetic map of the region at $19.5 \mathrm{~min}$ on the $E$. coli chromosome. The gene positions shown are based on Gottesman et al. (1990), Cummings et al. (1991), Delaney and Georgopoulos (1992), and Shrader et al. (1993). The known or predicted direction of transcription for each gene is indicated with an arrow. The chromosomal inserts present in plasmids pDS351, pDS71, and pDS75 are indicated.

as many other members of this family with an aminoterminal portion traversing the membrane multiple times and a carboxy-terminal cytoplasmic ATP-binding domain (Blight and Holland 1990).

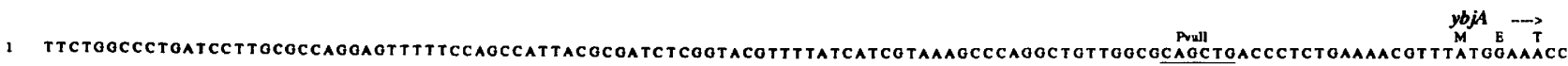

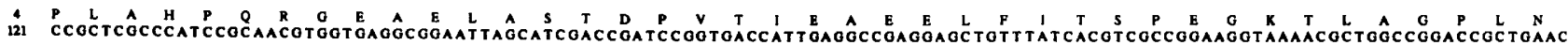

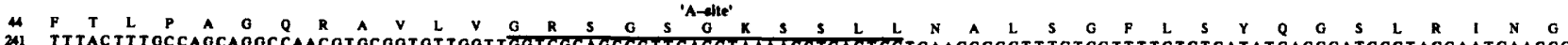

211 TTTACTTTOCCAOCAOGCCAACGTGCOOTOTTGOTTGOTCGCAGCGGTTCAGOTAAAAGCTCACTGCTOAACOCOCTTTCTGOTTTTCTCTCATATCAOGOATCOCTACOAATCAACGGO

34 L

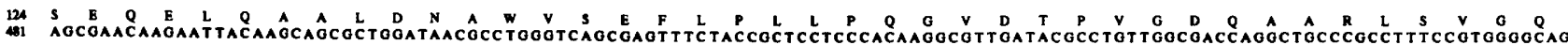

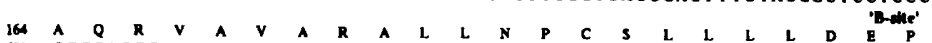

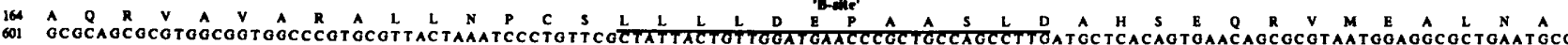

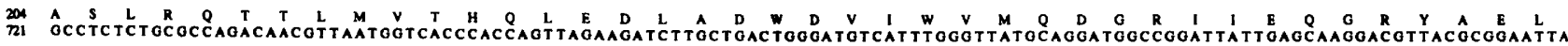

24: S S Y

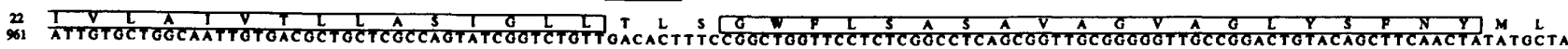

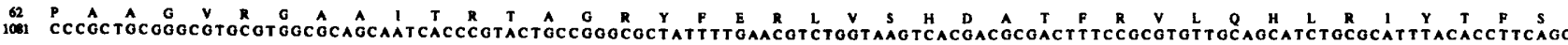

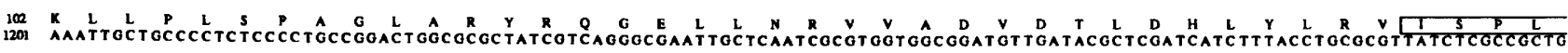

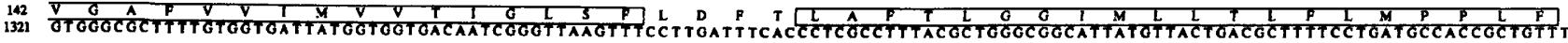

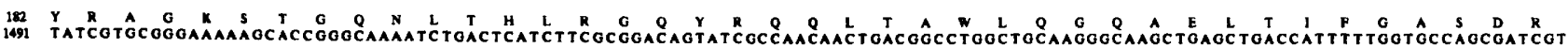

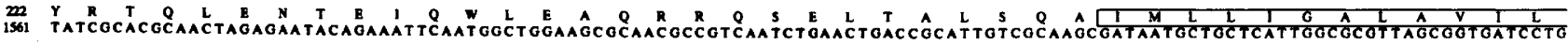

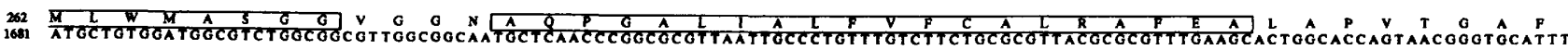

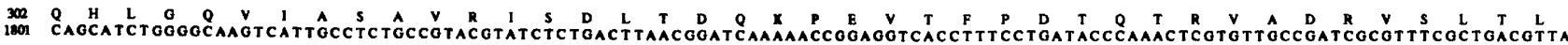

32
1921
C

201 L L L L L O

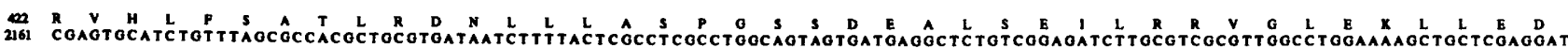

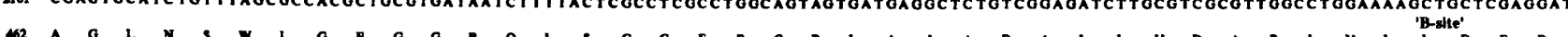

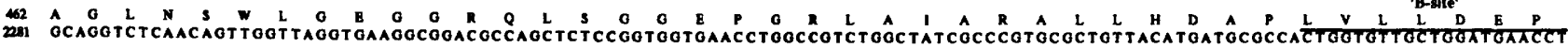

200

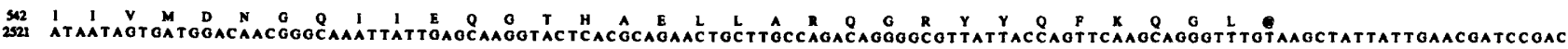

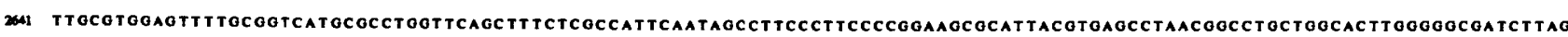
206 CTOCGCOCCTOTtaAtGgCtTACCAOCOTOOATtT
}

Figure 4. DNA sequence of $\operatorname{sur} B$ and $y b j A$. The position of the $\operatorname{sur} B 1:$ :mini-Tn 10 kan mutation is indicated $(\nabla)$. The predicted amino acid sequences of SurB and $\mathrm{YbjA}$ are shown above the nucleotide sequence. The highly conserved putative ATP-binding sites shared with other members of the ABC transporter family, the so-called A and B sites (Walker et al. 1982), are underlined. The putative ribosome-binding site for SurB is underlined. Potential membrane-spanning regions in SurB were identified on the basis of the hydropathy analysis shown in Fig. 5 and are boxed. 


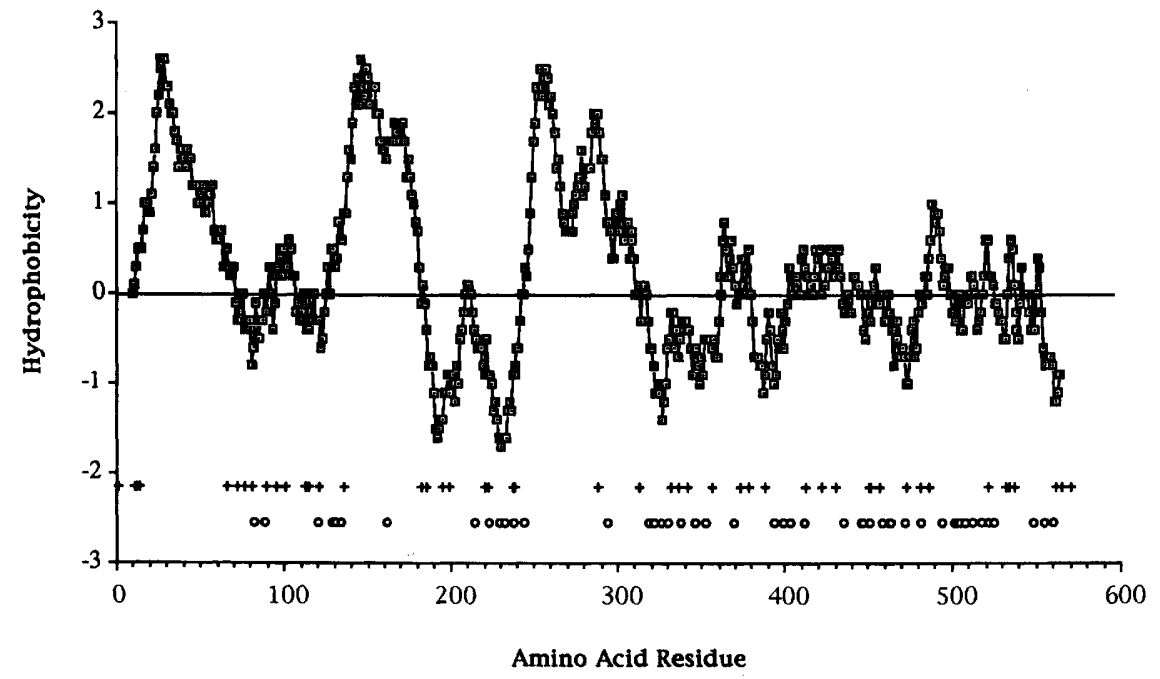

Figure 5. Hydrophobicity plot of the predicted SurB protein. Hydropathy analysis was performed using the algorithm of Kyte and Doolittle (1982) with a window length of 19 residues. Regions below zero are hydrophilic; regions above zero are hydrophobic, with regions greater than +1.6 being predicted membrane-spanning regions. The positions of positively and negatively charged amino acid residues are indicated. $(+\mid$ Lys or Arg residues; 101 Glu or Asp residues.
The inability to exit from stationary phase is attributable to loss of surB

Complementation with plasmid subclones indicated that the phenotype of the surB1 mutant was attributable to disruption of the $\operatorname{sur} B$ gene itself and not to polarity on expression of downstream genes. The aat, inf $A$, and ser $W$ genes are located downstream of $\operatorname{sur} B$ and oriented in the same direction as $\operatorname{sur} B$ (see Fig. 3). Transcript and promoter mapping of the middle gene, inf $A$, indicate that it is transcribed as a monocistronic message independently of the two flanking genes (Cummings et al. 1991). The serW gene is also reported to have its own promoter (cited in Cummings et al. 1991); therefore, it is unlikely that the surB1 insertion was polar on transcription of either of these two genes.

It was still possible that the surB1 insertion was polar on expression of aat. Cummings et al. (1991) identified two transcripts containing the aat gene by $S 1$ mapping. One transcript originates within $\operatorname{sur} B, \sim 100$ bp from the end of the sur $B$-coding region. The $5^{\prime}$ end of the second aat transcript was not identified, but it originates upstream of a site within $\operatorname{sur} B$. These data indicated that sur $B$ and at might be cotranscribed, but the aat gene may also have its own promoter.

Table 1. Complementation of surB $1:$ mini-Tn10 kan with plasmid subclones

\begin{tabular}{lc}
\hline & eop at $37^{\circ} \mathrm{C}$ \\
\hline surB1 pACYC184 & $0.5 \times 10^{-3}$ \\
surB1 pDS75 & 1.4 \\
ZK126 pACYC184 & 0.9 \\
ZK126 pDS75 & 1.8 \\
\hline
\end{tabular}

Stationary-phase cultures were titered on minimal glucose plates containing antibiotics and incubated at $23^{\circ} \mathrm{C}$ or $37^{\circ} \mathrm{C}$. The efficiency of plating (eop) at $37^{\circ} \mathrm{C}$ is the $\mathrm{CFU} / \mathrm{ml}$ at $37^{\circ} \mathrm{C}$ divided by the $\mathrm{CFU} / \mathrm{ml}$ at $23^{\circ} \mathrm{C}$.
To test whether the $\operatorname{sur} B$ gene alone was sufficient to complement the surB1 mutation, a plasmid was constructed that contained the $\operatorname{sur} B$ gene and in which the downstream genes, aat and $\inf A$, were inactivated by deletion of an internal KpnI fragment (serW is still intact on this plasmid). This plasmid, named pDS75, complemented the temperature-sensitive outgrowth phenotype of surB1 (Table 1). surB1 mutant cells containing pDS75 were able to resume growth and form colonies at $37^{\circ} \mathrm{C}$ after entering stationary phase.

\section{Stationary-phase surB1 cells respond to nutrients but do not initiate growth}

Once surB1 cells have entered stationary phase, they cannot resume growth and form colonies when plated at high temperature. A similar phenotype was seen when cells from a stationary-phase culture were diluted into fresh liquid growth medium at $37^{\circ} \mathrm{C}$. Only a small increase in optical density was observed (Fig. 6A) and no DNA synthesis was detected (Fig. 6B). The initial rates of RNA and protein synthesis in the surB1 strain were similar to the wild-type and mutant strains, but both of these processes appeared defective in the surB1 mutant by $20 \mathrm{~min}$ after addition of fresh nutrients.

In the wild-type strain, the rate of RNA synthesis per cell increased in two phases (Fig. 6C). There was an initial rapid increase (three- to 12 -fold) within the first 5 min after transfer to fresh growth medium. During the second phase the synthesis rate per cell continued to increase for $60 \mathrm{~min}$, but more slowly. In the surB1 strain only the initial increase (9- to 12-fold) in the rate of RNA synthesis was seen. The rate of RNA synthesis did not increase further. A qualitatively similar result was observed when protein synthesis was measured (Fig. 6D). These experiments indicate that stationary-phase surB1 cells can respond to an increase in nutrients but are unable to resume growth at the nonpermissive temperature. 


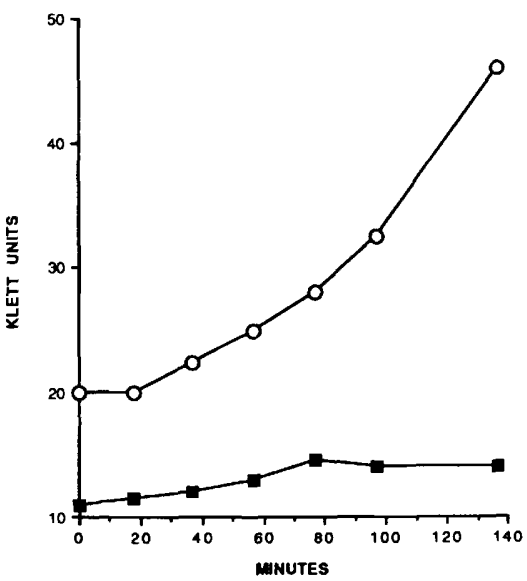

c

Figure 6. Synthesis of DNA, RNA, and protein during outgrowth from stationary phase. Stationary-phase cells were diluted into fresh minimal glucose medium at $37^{\circ} \mathrm{C}$. Labeling was done as described in the text. $(A)$ Optical density of cultures in Klett units; $(B)$ DNA synthesis; $(C)$ RNA synthesis; (D) protein synthesis. (O) ZK126; (日) ZK126 surB1.
B

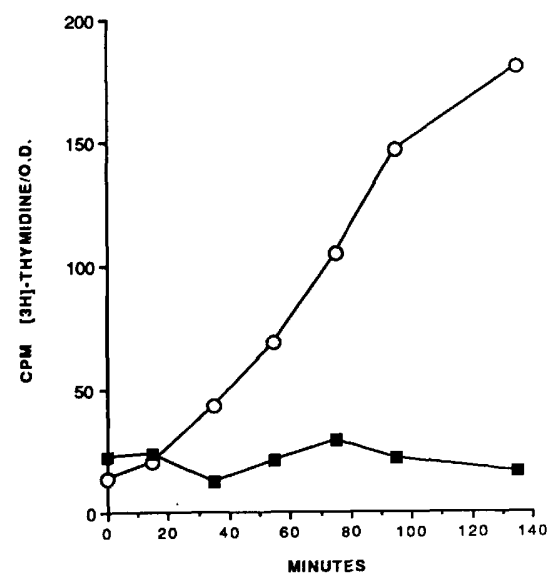

D

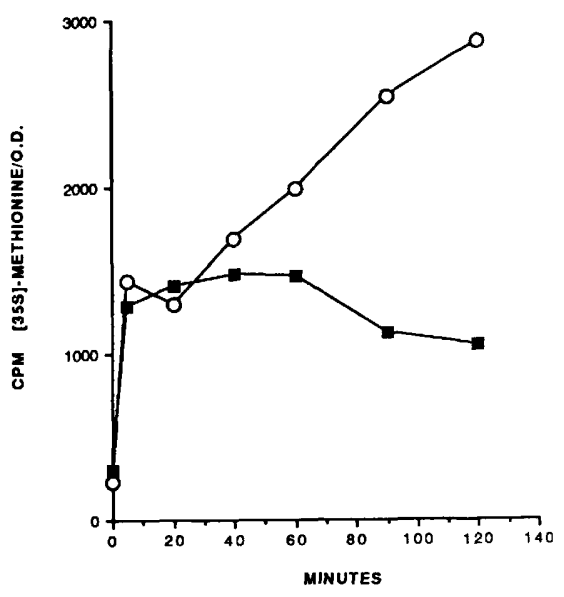

The surBl mutant also has phenotypes during exponential growth and stationary phase

Although surB1 was isolated because of its $\mathrm{Sur}^{-}$phenotype, we have also found that lack of the $\operatorname{sur} B$ product affects cells at other points in the growth cycle. surB1 cells were found to be hypersensitive to cysteine during exponential growth. As with other wild-type $E$. coli K-12 strains, growth of the parental strain ZK126 is inhibited by cysteine (Fig. 7A). This growth inhibition is the result of amino acid starvation caused by feedback inhibition of certain amino acid biosynthetic enzymes and is relieved by the addition of other amino acids (Datta 1967; Sørensen and Pedersen 1991). Growth of surB1 cells stopped completely with the addition of cysteine to a culture growing in minimal glucose medium at $37^{\circ} \mathrm{C}$ (Fig. 7B); even after $30 \mathrm{hr}$ the cells had not doubled (data not shown). The addition of other amino acids only partially relieved the inhibition of surB1 mutant cells by cysteine. Complete growth inhibition by cysteine was also seen when surB1 cells were growing at $25^{\circ} \mathrm{C}$ /data not shown).

To determine whether the surB1 mutation affected the pattern of gene expression during exponential growth or stationary phase, the proteins synthesized in surB1 and
A

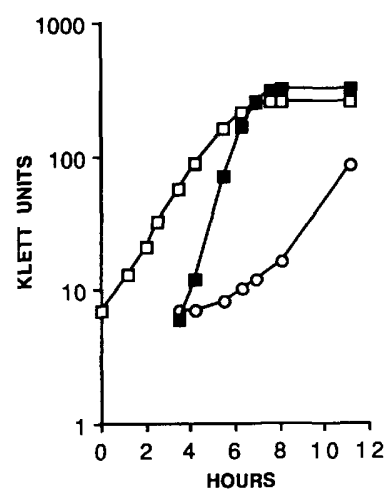

B

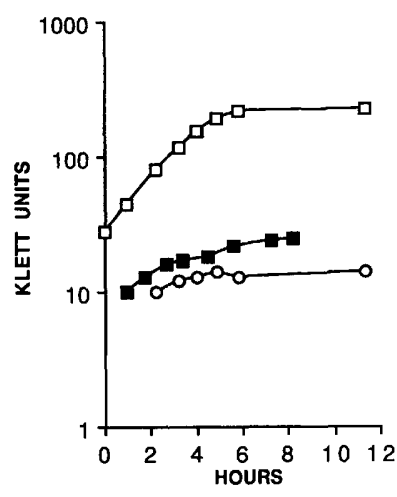

Figure 7. Nutritional shifts during exponential growth. ZK126 $(A)$ and ZK126 surB1 $(B)$ were grown in minimal glucose medium at $37^{\circ} \mathrm{C}(\square)$. During exponential growth, an aliquot of each culture was diluted into prewarmed minimal glucose medium containing either cysteine at $40 \mu \mathrm{g} / \mathrm{ml}(O)$ or all 20 amino acids, each at $40 \mu \mathrm{g} / \mathrm{ml}(\square)$. Growth of neither culture was affected by dilution into prewarmed minimal glucose medium without amino acids (not shown). Growth was monitored by measuring the optical density of each culture with a Klett-Summerson colorimeter. 
Table 2. The phenotype of surBl after glucose, ammonia, or phosphate starvation

\begin{tabular}{lclc}
\hline & \multicolumn{3}{c}{ Efficiency of plating at $37^{\circ} \mathrm{C}$} \\
\cline { 2 - 4 } & $\begin{array}{l}\text { glucose } \\
\text { starved }\end{array}$ & $\begin{array}{l}\mathrm{PO}_{4} \\
\text { starved }\end{array}$ & $\begin{array}{l}\mathrm{NH}_{4} \\
\text { starved }\end{array}$ \\
\hline Plated aerobically & $0.9 \times 10^{-4}$ & $1.3 \times 10^{-4}$ & 0.35 \\
Plated anaerobically & 0.85 & 0.75 & 0.57 \\
\hline
\end{tabular}

Cells were grown in minimal MOPS medium where the concentrations of glucose, ammonia, or phosphate were adjusted so that cells entered stationary phase as a result of exhaustion of that nutrient from the medium. Cells from stationary-phase cultures were placed on minimal glucose plates containing 10 $\mathrm{mM} \mathrm{KNO}_{3}$ and incubated at either $23^{\circ} \mathrm{C}$ or $37^{\circ} \mathrm{C}$ under aerobic conditions and at $37^{\circ} \mathrm{C}$ under anaerobic conditions. Anaerobic growth conditions were generated using the BBL GasPak System (Becton Dickinson, Cockeysville, MD). The efficiency of plating at $37^{\circ} \mathrm{C}$ is the $\mathrm{CFU} / \mathrm{ml}$ at $37^{\circ} \mathrm{C}$ divided by the $\mathrm{CFU} / \mathrm{ml}$ at $24^{\circ} \mathrm{C}$.

wild-type cells were compared. The surB1 mutation caused a change in the pattern of protein synthesis both during exponential growth and early in stationary phase (data not shown). As visualized by one-dimensional SDS-polyacrylamide gel electrophoresis, the surB1 mutation had a modest effect on the proteins synthesized during exponential growth. A more pleiotropic effect was seen on the pattern of proteins synthesized 1-2 hr after entry into stationary phase. These results raise the possibility that the failure of surB1 cells to exit from stationary phase at high temperature was the result of events that occurred earlier, such as during growth or when the cells were first entering stationary phase.

surB function is not required under all growth conditions

The $\operatorname{sur} B 1$ mutant was isolated by screening cultures where cells entered stationary phase after the glucose in the medium was exhausted. To determine whether the requirement for SurB function depended on what limiting nutrient prevented growth, we examined the pheno-

Table 3. In vivo assay for cytochrome d oxidase function

\begin{tabular}{lllll}
\hline & Glycerol & $\begin{array}{l}\text { Glycerol } \\
+\mathrm{Zn}^{+2}\end{array}$ & Glucose & $\begin{array}{r}\text { Glucose } \\
+\mathrm{Zn}^{+2}\end{array}$ \\
\hline ZK126 & $+(0.8)$ & $+(1.0)$ & $+(1.0)$ & $+(0.7)$ \\
$\begin{array}{l}\text { ZK126 } \\
\text { surB1 }\end{array}$ & $+(1.0)$ & $-\left(<1.0 \times 10^{-5}\right)$ & $+(1.0)$ & $+(1.6)$ \\
$\begin{array}{l}\text { ZK126 } \\
\text { scydAB-1 }\end{array}$ & $+(0.5)$ & $-\left(<1.0 \times 10^{-5}\right)$ & $+(1.0)$ & $+(1.1)$ \\
\hline
\end{tabular}

Cells from stationary-phase cultures were placed on minimal glucose or minimal glycerol medium containing, where indicated, $150 \mu \mathrm{M} \mathrm{ZnSO}_{4}$. Plates were incubated at $24^{\circ} \mathrm{C}$. The efficiency of plating on each medium is expressed relative to the number of CFU $/ \mathrm{ml}$ on minimal glucose plates and is given in parentheses.
Table 4. Comparison of $\triangle \mathrm{cydAB}$ and surBl phenotypes

\begin{tabular}{lll}
\hline & eop at $24^{\circ} \mathrm{C}$ & eop at $37^{\circ} \mathrm{C}$ \\
\hline ZK126 & $1\left(7 \times 10^{8}\right)$ & $2.0(1.5 \mathrm{~mm}$ diam $)$ \\
ZK126 surB1 & $1\left(8 \times 10^{8}\right)$ & $5.1 \times 10^{-4}(1.5 \mathrm{~mm}$ diam) \\
ZK126 $\triangle$ cydAB-1 & $1\left(1.1 \times 10^{9}\right)$ & 0.91 (pinpoint) \\
\hline
\end{tabular}

Stationary-phase cultures were titered on minimal glucose plates and incubated at either $24^{\circ} \mathrm{C}$ or $37^{\circ} \mathrm{C}$. The efficiency of plating (eop) at $24^{\circ} \mathrm{C}$ was defined as 1 . The eop at $37^{\circ} \mathrm{C}$ is the number of $\mathrm{CFU} / \mathrm{ml}$ at $37^{\circ} \mathrm{C}$ divided by the number of $\mathrm{CFU} / \mathrm{ml}$ at $24^{\circ} \mathrm{C}$. The $\mathrm{CFU} / \mathrm{ml}$ at $24^{\circ} \mathrm{C}$ is given in parentheses in the first column. Colony size at $37^{\circ} \mathrm{C}$ is given in parentheses in the second column.

type of $\operatorname{sur} B 1$ after growth in minimal medium where growth stopped and cells entered stationary phase as a result of exhaustion of glucose, ammonia, or phosphate. The results are shown in Table 2 . When surB1 cells entered stationary phase at $37^{\circ} \mathrm{C}$ as a result of exhaustion of either glucose or phosphate in the growth medium, they became temperature sensitive for the resumption of growth. In contrast, this phenotype was not seen under conditions of ammonia starvation.

The temperature-sensitive phenotype of the surB1 mutant was also tested under anaerobic growth conditions. Stationary-phase surB1 cells plated with the same efficiency at low and high temperature when the plates were incubated anaerobically (Table 2). Thus, the $\operatorname{sur} B$ gene product is not required to exit stationary phase under anaerobic growth conditions, even after glucose or phosphate starvation.

\section{surBl mutants lack functional cytochrome $\mathrm{d}$ oxidase}

The $\operatorname{sur} B$ gene mapped very near a previously described gene, cydC, the function of which is required for the formation of functional cytochrome $d$ oxidase, but which is unlinked to the structural genes for the enzyme $c y d A B$ (Georgiou et al. 1987; Calhoun et al. 1991). Cytochrome $d$ oxidase is one of two terminal oxidases in $E$. coli that function in aerobic electron transport; the other is cytochrome $o$ oxidase (Ingledew and Poole 1984; Gennis 1987). The cydC gene was defined by a $\lambda$ placMu53 insertion, which was mapped by Southern blot hybridization to a 1.1-kb BgII-PvuII fragment that overlaps the first $330 \mathrm{bp}$ of the predicted coding sequence of $\operatorname{sur} B$ (Delaney and Georgopolous 1992). Thus, cydC is the same gene as either $\operatorname{sur} B$ or $y b i A$.

To determine whether surB1 mutant cells produce functional cytochrome $d$ oxidase, we tested whether they could grow aerobically on glycerol in the presence of $\mathbf{Z n}^{2+}$ (Table 3). Aerobic growth on glycerol requires the function of either cytochrome $o$ or cytochrome $d$ oxidase. Cytochrome $o$ oxidase is more sensitive to inhibition by heavy metal ions, such as $\mathrm{Zn}^{2+}$, than cytochrome $d$ oxidase; therefore, aerobic growth on glycerol in the presence of $\mathrm{Zn}^{2+}$ can be used to test for functional cytochrome $d$ oxidase (Poole et al. 1989; Wall et al. 1992). The parental strain ZK126 grew on minimal 
glycerol medium in the presence or absence of $150 \mu \mathrm{M}$ $\mathrm{ZnSO}_{4}$, but neither the surB1 mutant nor a known $\triangle c y d A B$ mutant was able to grow on minimal glycerol medium containing $\mathrm{Zn}^{2+}$. All of the strains were able to grow on minimal glucose medium containing $150 \mu \mathrm{M}$ $\mathrm{ZnSO}_{4}$, showing that failure to grow on minimal glycerol medium with $\mathrm{Zn}^{2+}$ was not attributable to a general sensitivity to $\mathrm{Zn}^{2+}$.

These results raised the possibility that the $\mathrm{SurB}^{-}$ phenotype was the result of a cytochrome $d$ oxidase defect; however, the absence of cytochrome $d$ oxidase was not sufficient to cause a SurB ${ }^{-}$phenotype (Table 4). ZK126 $\triangle c y d A B-1:: k a n$ cells plated with the same efficiency at $23^{\circ} \mathrm{C}$ and $37^{\circ} \mathrm{C}$ after entering stationary phase. Under the same conditions, the plating efficiency of the surB1 mutant was $5.1 \times 10^{-4}$. Although stationary-phase $\triangle c y d A B-1:: k a n$ cells plated with the same efficiency at low and high temperature, they formed significantly smaller colonies at $37^{\circ} \mathrm{C}$ than the wild-type strain. This tiny colony phenotype was not seen when exponentially growing $\triangle$ cydAB-1::kan cells were plated at $37^{\circ} \mathrm{C}$ indicating that, similar to $\operatorname{sur} B 1$, the temperature-sensitive defect caused by $\triangle c y d A B-1:: k a n$ is specific for exiting stationary phase. Our result differs from the phenotype described previously by Wall et al. (1992), who found that exponential growth of $c y d A B^{-}$mutants was impaired at high temperature. The different phenotypes observed may be the result of the different growth media used or to differences in strain background, or both.

\section{Discussion}

Like many other microorganisms E. coli responds to nutritional deprivation by activating starvation or stationary-phase programs that allow it to shut down growth in an orderly manner and survive prolonged starvation (for review, see Matin 1991; Siegele and Kolter 1992). The differences in physiology and morphology characteristic of stationary-phase cells are at least partly the result of changes in gene expression that occur as cells enter stationary phase. Just as regulatory mechanisms controlling the response of growing bacterial cells to starvation adapt cell physiology to a nongrowing state, mechanisms regulating the response of stationary-phase cells to nutrients must control orderly reentry into the cell cycle.

Several lines of evidence support the idea of active regulation of the resumption of growth. First, there are numerous reports of starved bacteria that metabolize fresh nutrients but do not divide (Roszak and Colwell 1987; Oliver et al. 1991). This suggests that starved cells can respond to an increase in nutrients by choosing whether to grow or not to grow, depending on current conditions and past history of the cell.

Second, synthesis of specific proteins is induced during outgrowth from stationary phase. When stationaryphase $E$. coli cells are transferred to fresh medium the synthesis of Fis protein is induced and then falls to a lower level once growth is established (Ball et al. 1992; Ninnemann et al. 1992). This pattern can be understood in terms of Fis function as an activator of transcription of
rRNA operons (Nilsson et al. 1990; Ross et al. 1990). The number of ribosomes per cell decreases during many starvation conditions (Matin et al. 1989). Thus, the burst of Fis expression may function to establish a high rate of rRNA synthesis needed to replace the ribosomes degraded during stationary phase, as well as to synthesize new ones needed for growth. In the marine Vibrio sp. S14, a group of 11 proteins synthesized only during outgrowth from stationary phase has been identified (Albertson et al. 1990). Synthesis of these proteins is induced when nutrients are added to stationary-phase cells, and their synthesis is repressed once exponential growth has started. The timing of expression of such genes may be controlled by regulatory mechanisms that sense and respond to environmental conditions specific to the time of exiting from stationary phase. Programs of gene expression are also correlated with resumption of growth in eukaryotic cells. When serum-starved cells are returned to conditions that allow growth, a cascade of gene expression is initiated (Herschman 1991). The immediate-early genes, with synthesis that is induced by the addition of serum or growth factors to quiescent fibroblasts, include the Fos and Jun families of transcription factors.

Third, there appear to be functions that are required to initiate growth but are not needed to maintain growth and become dispensable once growth has started. In $\mathrm{Ba}$ cillus subtilis, the temperature-sensitive $g s p$ mutations define cellular functions essential only during spore outgrowth (Albertini et al. 1979). Mutant spores germinate normally at high temperature but then arrest growth at a specific stage, which is characteristic for each mutation. If germinated and allowed to outgrow for a period of time at low temperature, the mutants can be shifted to high temperature and grow normally. This is similar to the phenotype seen for surB1. Evidence for functions needed primarily for reinitiating growth may also be found in eukaryotic cells. The Fos and Jun protein families are needed for DNA synthesis when quiescent cells are stimulated to resume growth and also in exponentially growing cells, but individual members of each family may not be required at both times in the growth cycle (Kovary and Bravo 1991).

In this paper we describe a conditional E. coli mutant, surB1, that grows normally and remains viable during stationary phase but is unable to exit stationary phase and resume aerobic growth at high temperature. Thus, the $\operatorname{sur} B$ gene product is not required for cell survival per se but, rather, is required for starved cells to reinitiate growth under restrictive conditions. Once growth has started, SurB function is no longer required.

What is the role of SurB during the resumption of growth? Cells lacking SurB sense and respond to increased levels of glucose with increased rates of RNA and protein synthesis but appear to arrest growth before the first cell division. This phenotype suggests that SurB might have a direct or indirect role in a regulatory process controlling reentry into the cell cycle. SurB could function directly in the regulatory pathway or could have an indirect role and be required for synthesis or 
assembly of the regulatory apparatus. Alternatively, the signal to resume growth may be generated in surB1 cells, but mutant cells are unable to grow because SurB is part of the cellular machinery needed for growth.

Although the SurB ${ }^{-}$phenotype is manifested during outgrowth from stationary phase, surB1 mutants also have phenotypes during exponential growth and stationary phase. surB1 mutants are sensitive to certain nutritional upshifts during exponential growth at high temperature and also have an altered pattern of gene expression early in stationary phase. This raises the possibility that the inability of mutant cells to resume growth after starvation is the consequence of events that occurred earlier in the growth cycle. It is known that changes occurring as cells enter stationary phase affect their ability to survive prolonged starvation (Reeve et al. 1984a; Lange and Hengge-Aronis 1991; McCann et al. 1991). Events that occur during the transition between the growth and stationary phases or that occur during stationary phase may also have an effect on the ability of cells to reenter the cell cycle.

The predicted amino acid sequence of SurB indicates that it is a member of the $A B C$ family of transport proteins, a large family of ATP-binding proteins, many of which are involved in diverse transport processes (Blight and Holland 1990). SurB not only shares the conserved ATP-binding region but is also predicted to be an integral membrane protein with several possible membranespanning regions; therefore, it is likely that SurB also functions as a transporter. The gene immediately upstream of $\operatorname{sur} B-y b i A-$ is also predicted to encode a protein homologous to the $\mathrm{ABC}$ transporter family, and it is possible that SurB and YbjA may function together as subunits of a transport system. Some members of the $\mathrm{ABC}$ family of transporters are known to be involved in sensing or responding to environmental changes. For example, the products of the spoOK operon are required for sporulation and the development of competence in $B$. subtilis. These proteins may function by importing an extracellular signal molecule (Perego et al. 1991; Rudner et al. 1991).

Physical mapping indicated that either $\operatorname{sur} B$ or $y b j A$ may be the same as $c y d C$, a gene described previously whose function is needed for production of functional cytochrome $d$ oxidase (Georgiou et al. 1987). cydC does not encode a cytochrome $d$ oxidase subunit; rather, in a cyd $C^{-}$mutant the cytochrome $d$ oxidase complexes are missing heme- $d$. Consistent with the mapping, surB1 mutant cells were shown to lack cytochrome $d$ oxidase function. The absence of cytochrome $d$ oxidase was not sufficient to cause the $\mathrm{SurB}^{-}$phenotype, although cells with a deletion of the cytochrome $d$ oxidase structural genes, $\triangle c y d A B$, also showed a temperature-sensitive defect in exiting stationary phase. It is possible that the absence of cytochrome $d$ oxidase function contributes to the SurB ${ }^{-}$phenotype; but as the phenotypes of surB1 and $\triangle c y d A B-1$ mutants are not identical, SurB may have an additional role in the cell.

surB1 is an insertion mutation that causes a temperature-sensitive phenotype. Although there is precedent for temperature-sensitive insertion mutations in $E$. coli (Lipinska et al. 1989) and yeast (Kawakami et al. 1992), insertion mutations are not generally expected to confer conditional phenotypes. To determine the phenotype of a true $\operatorname{sur} B$ null mutation, a deletion mutation was constructed. In $\Delta$ surB2::mini-Tn10 kan, a mini-Tn10 kan replaces codons $21-448$ of the ORF. Cells with the $\triangle$ surB2 allele have the same temperature-sensitive growth defect as the original surB1 mutant /data not shown), indicating that surB1 is a null allele. Thus, SurB activity is only required when cells are at high temperature and is not needed during outgrowth from stationary phase at low temperature. The temperature sensitivity of $\operatorname{sur} B$ null mutants could be explained if $\operatorname{sur} B$ encodes a redundant function and the expression or activity of other gene products that perform the same function as SurB is inherently temperature sensitive. Alternatively, the function carried out by SurB may be required only when cells are at high temperature and dispensable at low temperature.

Although SurB is required for cells to exit from stationary phase and resume growth under some conditions, we have shown that its function is not required under all conditions. Because the physiology of the stationary-phase cell differs under different starvation conditions, it is likely that the proteins required for reentering exponential growth vary and will depend on the metabolic conditions of the cell at the onset of starvation, during starvation, and during reinitiation of growth.

\section{Materials and methods}

Bacteria, bacteriophages, and plasmids

All bacterial strains used were $E$. coli $\mathrm{K}-12$ derivatives. ZK126 is W3110 AlacU169 tna-2 (Connell et al. 1987); DS28 is ZK126 surB1::mini-Tn10 kan (this work); ECL937 is ECL525 $\Phi$ (cyolac) bla ${ }^{+} \Delta c y d A B-1:: k a n$ (Iuchi et al. 1990); DS126 is ZK126 $\triangle$ cydAB-1::kan (this work); MC1061 is araD139 $\Delta$ (ara-leu)7697 $\Delta($ lac $)$ X74 galU galK rpsL $\left(\mathrm{Sm}^{\mathrm{R}}\right)$ hsdR $h s d M^{+}$hsdS ${ }^{+}$(Casadaban and Cohen 1980); $71-18$ is supE thi $\Delta\left(\right.$ lac-proAB)/F $\mathrm{F}^{\prime}$ pro $A^{+} B^{+}$ lacI ${ }^{\mathrm{Q}}$ lacZDM15 (Messing et al. 1977). Strain ECL937 was kindly provided by S. Iuchi and E.C.C. Lin (Department of Microbiology and Molecular Genetics, Harvard Medical School, Boston, MA). Plasmid pDS351 contains an $8.5 \cdot \mathrm{kb}$ chromosomal PstI fragment carrying the surB1::mini-Tn10 kan insertion cloned into the PstI site of pUC19 (Yanisch-Perron et al. 1985). Plasmid pDS71 contains the wild-type surB gene on a $5.5-\mathrm{kb}$ chromosomal EcoRI fragment cloned into the EcoRI site of pACYC184 (Chang and Cohen 1978; Rose 1988). The chromosomal insert in pDS71 was obtained from Kohara phage $\lambda 214$ (Kohara et al. 1984). Plasmid pDS75 was derived from pDS71 by deletion of an internal KpnI fragment; deletion of this KpnI fragment inactivates the aat and $\inf A$ genes on the plasmid. Phage $\lambda$ NK1105 was used to introduce the mini-Tn10 kan transposon as described (Way et al. 1984). Transductions were done using phage P1vir. The Kohara miniset of $\lambda$ phages containing the ordered library of the E. coli K-12 W3110 chromosome (Kohara et al. 1984) was kindly provided by Dr. Kenn Rudd [National Center for Biotechnology Information (NCBI)].

\section{Media}

M63 minimal medium was made according to Miller (Miller 
1972) except that $\mathrm{FeSO}_{4}$ was omitted. Glucose was added to $0.2 \%$, and casamino acids (Difco, vitamin free) were added to $0.1 \%$, unless stated otherwise. When present, kanamycin was added to $50 \mu \mathrm{g} / \mathrm{ml}$, tetracycline to $12.5 \mu \mathrm{g} / \mathrm{ml}$, and chloramphenicol to $20 \mu \mathrm{g} / \mathrm{ml}$. MOPS minimal medium was made according to Neidhardt et al. (1974). For glucose-starved cultures the medium contained $0.05 \%$ glucose, $1.32 \mathrm{mM} \mathrm{K}_{2} \mathrm{HPO}_{4}$, and $9.5 \mathrm{mM} \mathrm{NH}_{4} \mathrm{Cl}$. For phosphate- and ammonia-starved cultures the media contained $0.2 \%$ glucose, and the phosphate or ammonia concentrations were reduced to $0.066 \mathrm{mM} \mathrm{K}_{2} \mathrm{HPO}_{4}$ or 1.1 $\mathrm{mM} \mathrm{NH}_{4} \mathrm{Cl}$, respectively. Cells grew to the same density in each MOPS medium, $\sim 1 \times 10^{8} \mathrm{CFU} / \mathrm{ml}$. Minimal glycerol medium to test for functional cytochrome $d$ oxidase was made as described (Poole et al. 1989; Wall et al. 1992) with the following modifications: The trace elements solution described by Neidhardt et al. (1974) was used; glycerol 3-phosphate and $\mathrm{NaN}_{3}$ were omitted and, when present, $\mathrm{ZnSO}_{4}$ was added to a final concentration of $150 \mu \mathrm{M}$.

\section{Screen for Sur- mutants}

A collection of independent random transposon insertion mutants was generated by infecting ZK126 with phage $\lambda 1105$ as described (Way et al. 1984). The insertion mutants were screened for stationary-phase survival defects (a Sur ${ }^{-}$phenotype) as described (Tormo et al. 1990). Briefly, individual cultures of each of the insertion mutants were grown in mninimal glucose medium in wells of microtiter plates and kept in stationary phase at $37^{\circ} \mathrm{C}$ for 10 days. An aliquot of each culture was then plated on M63 glucose $\mathrm{Km}$ plates, and the number of CFU per milliliter remaining was compared with the wild-type strain ZK126. To recover the Sur ${ }^{-}$mutants identifed by the screen, duplicate cultures of the insertion mutants were inoculated and one set of cultures was frozen at $-70^{\circ} \mathrm{C}$, while the cells were still growing.

\section{Cloning and mapping of the surB gene}

Restriction enzymes and T4 DNA ligase were purchased from New England BioLabs (Beverly, MA) and used as recommended by the manufacturer. To make a genomic library of $E$. coli strain DS28, DNA was purified from DS28 cells, completely digested with restriction endonuclease $P$ stI , and ligated with the plasmid pUC19 also digested with PstI. This genomic library was introduced into strain MC1061 by transformation of calcium chloride-competent cells and transformants selected on $\mathrm{LB}$ plates containing ampicillin and kanamycin. All of the $\mathrm{Ap}^{\mathrm{R}} \mathrm{Km}^{\mathrm{R}}$ transformants obtained contained a common PstI fragment of $10.3 \mathrm{~kb}$, which corresponded to a $8.5-\mathrm{kb}$ chromosomal fragment containing the $1.8 \mathrm{~kb}$ transposon. To map the fragment, one of these plasmids, designated pDS351, was radioactively labeled and hybridized to a nylon membrane carrying DNA from each phage of the Kohara library miniset (Kohara et al. 1984). DNA preparation, nick translation, plaque lifts, and hybridizations were performed using standard methods (Sambrook et al. 1989).

\section{DNA sequencing}

DNA sequence analysis was performed by the chain termination method (Sanger et al. 1977) using Sequenase (U.S. Biochemical, Cleveland, $\mathrm{OH}$ ) as recommended by the manufacturer. To obtain templates for DNA sequencing, plasmid pDS351 was digested with $P v u I I$, the fragment containing the surB1 insertion cut from a $1 \%$ agarose gel, the DNA extracted with GeneClean (Biol01, La Jolla, CA), digested with BamHI, and ligated with EcoRV- and BamHI-digested M13tg130 and M13tg131
(Kieny et al. 1983) double-stranded replicative form DNA. Strain 71-18 was used to propagate recombinant M13 phages and single-stranded M13 DNA purified using standard protocols (Sambrook et al. 1989). Oligonucleotides of 15-17 bases were used as primers to obtain the sequence of both strands of the chromosomal insert. The first primer used was the universal primer for M13. The remaining primers were derived from the sequenced region. To obtain DNA sequence beyond the ends of the PvuII fragment plasmid pDS71 was used as a template. The complete nucleotide sequence of $\operatorname{sur} B$ and ybiA has been submitted to GenBank (accession number L25859) and to the $E$. coli data base (Dr. Kenn Rudd, NCBI).

\section{Sequence analysis}

Comparison of the translated $\operatorname{sur} B$ and $y b j A$ sequences to the NBRF (PIR), SwissProt, and translated GenBank data bases was performed at the NCBI using the BLAST network service (Altschul et al. 1990). Hydropathy analysis of the translated $\operatorname{sur} B$ sequence was done on the MBCRR computer using the algorithm of Kyte and Doolitte (1982) with a 19-amino-acid residue window.

\section{Total DNA, RNA, and protein synthesis determinations}

Stationary-phase cultures of ZK126 or ZK126 surB1 were diluted 1:20 into prewarmed M63 glucose medium containing 12 amino acids minus methionine $(40 \mu \mathrm{g} / \mathrm{ml})$ at $37^{\circ} \mathrm{C}$. For DNA synthesis determinations, samples were pulsed for $1 \mathrm{~min}$ with $2 \mu \mathrm{Ci}$ of $\left[\right.$ methyl $-{ }^{3} \mathrm{H}$ ] thymidine $(89 \mathrm{Ci} / \mathrm{mmole}$; Amersham TRK.758). For RNA synthesis determinations, $0.5-\mathrm{ml}$ samples were pulsed for $1 \mathrm{~min}$ with $1 \mu \mathrm{Ci}$ of $\left[5,6-{ }^{3} \mathrm{H}\right]$ uridine $(47 \mathrm{Ci}$ / mmole; Amersham TRK.410). For protein synthesis determination, $0.5-\mathrm{ml}$ samples were pulsed for $1 \mathrm{~min}$ with $1 \mu \mathrm{Ci}$ of I- $\left[{ }^{35} \mathrm{~S}\right]$ methionine (1067 Ci/mmole; Amersham SJ.1515). After the 1-min pulse, samples for measuring DNA and RNA synthesis were quenched with $4 \mathrm{ml}$ of ice-cold $7.5 \% \mathrm{TCA}$, and $50 \mu \mathrm{g}$ of salmon sperm DNA was added as carrier. Samples were kept on ice for $\geqslant 15 \mathrm{~min}$, collected on GF/A filter disks, and counted. Samples for measuring protein synthesis were quenched with $1.5 \mathrm{ml}$ of ice-cold $7.5 \%$ TCA for $\geqslant 60 \mathrm{~min}$. Samples were heated at $90^{\circ} \mathrm{C}$ for $30 \mathrm{~min}$, cooled, then collected on GF/A filter disks and counted. The levels of DNA, RNA, and protein synthesis in stationary-phase cells were determined in the same way, except that the cells were diluted 1:20 into $0.5 \mathrm{ml}$ of M63 salts before labeling. Experiments were repeated at least twice. Data from a representative experiment are shown in Figure 6.

\section{Acknowledgments}

We thank Drs. Tom Shrader and Alex Varshavsky and Drs. John Delaney and Costa Georgopoulos for the communication of results and sharing sequence before publication. We thank Ms. Linda Cooksey for technical assistance. We thank Drs. Jim Hu and Alan Grossman for helpful discussions and critical reading of the manuscript. This work was supported by a grant from the National Science Foundation to R.K. (MCB9207323). D.A.S. was recipient of a U.S. Public Health Service postdoctoral fellowship (GM13781). R.K. was the recipient of an American Cancer Society Faculty Research Award (FRA 350).

The publication costs of this article were defrayed in part by payment of page charges. This article must therefore be hereby marked "advertisement" in accordance with 18 USC section 1734 solely to indicate this fact. 


\section{Note added in proof}

The $\operatorname{sur} B$ ORF was also sequenced by Shrader et al. (1993) and designated $m d r H$ (GenBank accession number L10383). surB and ybjA have recently been shown to be the same genes as cydC and cydD, respectively (Poole et al. 1993. Mol. Microbiol. 10: $421-430$ ).

\section{References}

Albertini, A.M., M.L. Baldi, E. Ferrari, E. Isnenghi, M.T. Zambelli, and A. Galizzi. 1979. Mutants of Bacillus subtilis affected in spore outgrowth. J. Gen. Microbiol. 110: 351-363.

Albertson, N.H., T. Nyström, and S. Kjelleberg. 1990. Macromolecular synthesis during recovery of the marine Vibrio sp. S14 from starvation. J. Gen. Microbiol. 136: 2201-2207.

Altschul, S.F., W. Gish, W. Miller, E.W. Myers, and D.J. Lipman. 1990. Basic local alignment search tool. J. Mol. Biol. 215: $403-410$.

Ames, G.F.-L., C.S. Mimura, and V. Shyamala. 1990. Bacterial periplasmic permeases belong to a family of transport proteins operating from Escherichia coli to human: Traffic ATPases. FEMS Microbiol. Rev. 6: 429-446.

Ball, C.A., R. Osuna, K.C. Ferguson, and R.C. Johnson. 1992. Dramatic changes in Fis levels upon nutrient upshift in Escherichia coli. J. Bacteriol. 174: 8043-8056.

Blight, M.A. and I.B. Holland. 1990. Structure and function of haemolysin B, P-glycoprotein and other members of a novel family of membrane translocators. Mol. Microbiol. 4: 873880.

Calhoun, M.W., G. Newton, and R.B. Gennis. 1991. Physical map locations of genes encoding components of the aerobic respiratory chain of Escherichia coli. J. Bacteriol. 173: 15691570.

Casadaban, M.J. and S.N. Cohen. 1980. Analysis of gene control signals by DNA fusion and cloning in Escherichia coli. I. Mol. Biol. 138: 179-207.

Chang, A.C.Y. and S.N. Cohen. 1978. Construction and characterization of amplifiable multicopy DNA cloning vehicles derived from the P15A cryptic miniplasmid. J. Bacteriol. 134: 1141-1156.

Connell, N., Z. Han, F. Moreno, and R. Kolter. 1987. An E. coli promoter induced by the cessation of growth. Mol. Microbiol. 1: 195-201.

Cummings, H.S., J.F. Sands, P.C. Foreman, J. Fraser, and J.W.B. Hershey. 1991. Structure and expression of the inf $A$ operon encoding translational initiation factor IF1. J. Biol. Chem. 266: 16491-16498.

Datta, P. 1967. Regulation of homoserine biosynthesis by L-cysteine, a terminal metabolite of a linked pathway. Proc. Natl. Acad. Sci. 58: 635-641.

Delaney, J.M. and C. Georgopolous. 1992. Physical map location of the $\operatorname{trx} B, h \operatorname{tr} D$, cydC, and $c y d D$ genes of Escherichia coli. J. Bacteriol. 174: 3824-3825.

Gennis, R.B. 1987. The cytochromes of Escherichia coli. FEMS Microbiol. Rev. 46: 389-399.

Georgiou, C.D., H. Fang, and R.B. Gennis. 1987. Identification of the cydC locus required for expression of the functional form of the cytochrome $d$ terminal oxidase complex in Escherichia coli. J. Bacteriol. 169: 2107-2112.

Gold, L. and G. Stormo. 1987. Translational initiation. In Escherichia coli and Salmonella typhimurium cellular and molecular biology (ed. F.C. Neidhardt, J.L. Ingraham, K.B. Low, B. Magasanik, M. Schaechter, and H.E. Umbarger), pp. 13021307. American Society for Microbiology, Washington, D.C.

Gottesman, S., W.P. Clark, and M.R. Maurizi. 1990. The ATPdependent Clp protease of Escherichia coli. Sequence of $\operatorname{clp} A$ and identification of a Clp-specific substrate. J. Biol. Chem. 265: 7886-7893.

Herschman, H.R. 1991. Primary response genes induced by growth factors and tumor promoters. Annu. Rev. Biochem. 60: 281-319.

Hyde, S.C., P. Emsley, M.J. Hartshorn, M.M. Mimmack, U. Gileadi, S.R. Pearce, M.P. Gallagher, D.R. Gill, R.E. Hubbard, and C.F. Higgins. 1990. Structural model of ATP-binding proteins associated with cystic fibrosis, multidrug resistance and bacterial transport. Nature 346: 362-365.

Ingledew, W.J. and R.K. Poole. 1984. The respiratory chains of Escherichia coli. Microbiol. Rev. 48: 222-271.

Iuchi, S., V. Chepuri, H.-A. Fu, R.B. Gennis, and E.C.C. Lin. 1990. Requirement for terminal cytochromes in generation of the aerobic signal for the arc regulatory system in Escherichia coli: Study utilizing deletions and lac fusions of cyo and cyd. J. Bacteriol. 172: 6020-6025.

Kawakami, K., B.K. Shafer, D.J. Garfinkel, J.N. Strathern, and Y. Nakamura. 1992. Ty element-induced temperature-sensitive mutations of Saccharomyces cerevisiae. Genetics 131: 821-832.

Kieny, M.P., R. Lathe, and J.P. Lecocq. 1983. New versatile cloning and sequencing vectors based on bacteriophage M13. Gene 26: 91-99.

Kjelleberg, S., M. Hermansson, P. Mårdén, and G.W. Jones. 1987. The transient phase between growth and nongrowth of heterotrophic bacteria, with emphasis on the marine environment. Ann. Rev. Microbiol. 41: 25-49.

Kohara, Y., K. Akiyama, and K. Isono. 1984. The physical map of the whole E. coli chromosome: Application of a new strategy for rapid analysis and sorting of a large genomic library. Cell 50: 495-508.

Kovary, K. and R. Bravo. 1991. The Jun and Fos protein families are both required for cell cycle progression in fibroblasts. Mol. Cell. Biol. 11: 4466-4472.

Kyte, J. and R.F. Doolittle. 1982. A simple method for displaying the hydropathic character of a protein. J. Mol. Biol. 157: 105132.

Lange, R. and R. Hengge-Aronis. 1991. Identification of a central regulator of stationary phase gene expression in Escherichia coli. Mol. Microbiol. 5: 49-59.

Li, C. and S. Clarke. 1992. A protein methyltransferase specific for altered aspartyl residues is important in Escherichia coli stationary-phase survival and heat-shock resistance. Proc. Natl. Acad. Sci. 89: 9885-9889.

Lipinska, B., O. Fayet, L. Baird, and C. Georgopoulos. 1989. Identification, characterization, and mapping of the Escherichia coli htrA gene, whose product is essential for bacterial growth only at elevated temperatures. I. Bacteriol. 171: 1575-1584.

Losick, R., P. Youngman, and P.J. Piggot. 1986. Genetics of endospore formation in Bacillus subtilis. Annu. Rev. Genet. 20: 625-669.

Mach, H., M. Hecker, I. Hill, A. Schroeter, and F. Mach. 1989. Stringent control and starvation survival in Escherichia coli. Z. Naturforsch. 44c: 838-844.

Malone, R.E. 1990. Dual regulation of meiosis in yeast. Cell 61: 375-378.

Matin, A. 1991. The molecular basis of carbon-starvation-induced general resistance in Escherichia coli. Mol. Microbiol. 5: 3-10.

Matin, A., E.A. Auger, P.H. Blum, and J.E. Schultz. 1989. Genetic basis of starvation survival in nondifferentiating bacteria. Annu. Rev. Microbiol. 43: 293-316.

McCann, M.P., J.P. Kidwell, and A. Matin. 1991. The putative $\sigma$ factor KatF has a central role in development of starvation- 
mediated general resistance in Escherichia coli. J. Bacteriol. 173: 4188-4194.

Messing, J., B. Gronenborn, B. Müller-Hill, and P.H. Hofschneider. 1977. Filamentous coliphage M13 as a cloning vehicle: Insertion of a HindII fragment of the lac regulatory region in M13 replicative form in vitro. Proc. Natl. Acad. Sci. 74: 3642-3646.

Miller, J.H. 1972. Experiments in molecular genetics. Cold Spring Harbor Laboratory, Cold Spring Harbor, New York.

Neidhardt, F.C., P.L. Bloch, and D.F. Smith. 1974. Culture medium for enterobacteria. J. Bacteriol. 119: 736-747.

Nierlich, D. 1992. Genetics nomenclature enters the computer age. ASM News 58: 645-646.

Nilsson, L., A. Vanet, E. Vijgenboom, and L. Bosch. 1990. The role of FIS in trans activation of stable RNA operons of $E$. coli. EMBO /. 9: 727-734.

Ninnemann, O., C. Koch, and R. Kahmann. 1992. The E. coli fis promoter is subject to stringent control and autoregulation. EMBO I. 11: 1075-1083.

Oliver, J.D., L. Nilsson, and S. Kjelleberg. 1991. Formation of nonculturable Vibrio vulnificus cells and its relationship to the starvation state. Appl. Environ. Microbiol. 57: 26402644.

Perego, M., C.F. Higgins, S.R. Pearce, M.P. Gallagher, and J.A. Hoch. 1991. The oligopeptide transport system of Bacillus subtilis plays a role in the initiation of sporulation. Mol. Microbiol. 5: 173-195.

Poole, R.K., H.D. Williams, J.A. Downie, and F. Gibson. 1989. Mutations affecting the cytochrome $d$-containing oxidase complex of Escherichia coli K12: Identification and mapping of a fourth locus, cydD. I. Gen. Microbiol. 135: 1865-1874.

Reeve, C.A., P.S. Amy, and A. Matin. 1984a. Role of protein synthesis in the survival of carbon-starved Escherichia coli K-12. J. Bacteriol. 160: 1041-1046.

Reeve, C.A., A.T. Bockman, and A. Matin. 1984b. Role of protein degradation in the survival of carbon-starved Escherichia coli and Salmonella typhimurium. J. Bacteriol. 157: 758763.

Rose, R.E. 1988. The nucleotide sequence of pACYC184. Nucleic Acids Res. 16: 355.

Ross, W., J.F. Thompson, J.T. Newlands, and R.L. Gourse. 1990. E. coli Fis protein activates ribosomal RNA transcription in vitro and in vivo. EMBO I. 9: 3733-3742.

Roszak, D.B. and R.R. Colwell. 1987. Survival strategies of bacteria in the natural environment. Microbiol. Rev. 51: 365379.

Rudner, D.Z., J.R. LeDeaux, K. Ireton, and A.D. Grossman. 1991. The spoOK locus of Bacillus subtilis is homologous to the oligopeptide permease locus and is required for sporulation and competence. I. Bacteriol. 173: 1388-1398.

Sambrook, J., E.F. Fritsch, and T. Maniatis. 1989. Molecular cloning: A laboratory manual. Cold Spring Harbor Laboratory Press, Cold Spring Harbor, New York.

Sanger, F., S. Nicklen, and A.R. Coulson. 1977. DNA sequencing with chain termination inhibitors. Proc. Natl. Acad. Sci. 74: 5463-5467.

Shimkets, L.J. 1990. Social and developmental biology of the myxobacteria. Microbiol. Rev. 54: 473-501.

Shrader, T.E., J.W. Tobias, and A. Varshavsky. 1993. The N-end rule in Escherichia coli: Cloning and analysis of the leucyl, phenylalanyl-tRNA-protein transferase gene aat. I. Bacteriol. 175:4364-4374.

Siegele, D.A., M. Almirón, and R. Kolter. 1993. Approaches to the study of survival and death in stationary-phase Escherichia coli. In Starvation in bacteria (ed. S. Kjelleberg), pp. 151-169. Plenum Press, New York.
Siegele, D.A. and R. Kolter. 1992. Life after log. I. Bacteriol. 174: 345-348.

Sørensen, M.A. and S. Pedersen. 1991. Cysteine, even in low concentrations, induces transient amino acid starvation in Escherichia coli. J. Bacteriol. 173: 5244-5246.

Spence, J., A. Cegielska, and C. Georgopoulos. 1990. Role of Escherichia coli heat shock proteins DnaK and HtpG (C62.5) in response to nutritional deprivation. I. Bacteriol. 172: 7157-7166.

Tormo, A., M. Almirón, and R. Kolter. 1990. surA, an Escherichia coli gene essential for survival in stationary phase. $J$. Bacteriol. 172: 4339-4347.

Traxler, B., D. Boyd, and J. Beckwith. 1993. The analysis of membrane protein topology. J. Membr. Biol. 132: 1-11.

Walker, J.E., M. Saraste, M.J. Runswick, and N.J. Gay. 1982. Distantly related sequences in the $\alpha$ - and $\beta$-subunits of ATP synthase, myosin, kinases and other ATP-requiring enzymes and a common nucleotide binding fold. EMBO J. 1: 945-951.

Wall, D., J.M. Delaney, O. Fayet, B. Lipinska, T. Yamamoto, and C. Georgopoulos. 1992. arc-dependent thermal regulation and extragenic suppression of the Escherichia coli cytochrome $d$ operon. J. Bacteriol. 174: 6554-6562.

Way, J.C., M.A. Davis, D. Morisato, D.E. Roberts, and N. Kleckner. 1984. New Tn10 derivatives for transposon mutagenesis and for construction of $l a c Z$ operon fusions by transposition. Gene 32: 369-379.

Yanisch-Perron, C., J. Vieira, and J. Messing. 1985. Improved M13 phage cloning vectors and host strains: Nucleotide sequences of the M13mpl 8 and pUC19 vectors. Gene 33: 103119. 


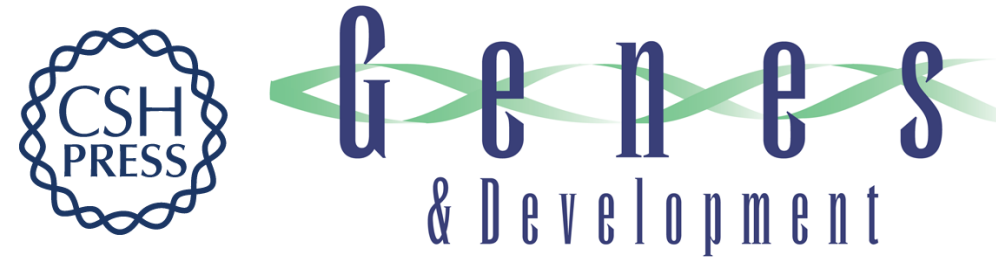

\section{Isolation and characterization of an Escherichia coli mutant defective in resuming growth after starvation.}

D A Siegele and R Kolter

Genes Dev. 1993, 7:

Access the most recent version at doi:10.1101/gad.7.12b.2629

References This article cites 61 articles, 29 of which can be accessed free at:

http://genesdev.cshlp.org/content/7/12b/2629.full.html\#ref-list-1

License

Email Alerting

Service

Receive free email alerts when new articles cite this article - sign up in the box at the top right corner of the article or click here.

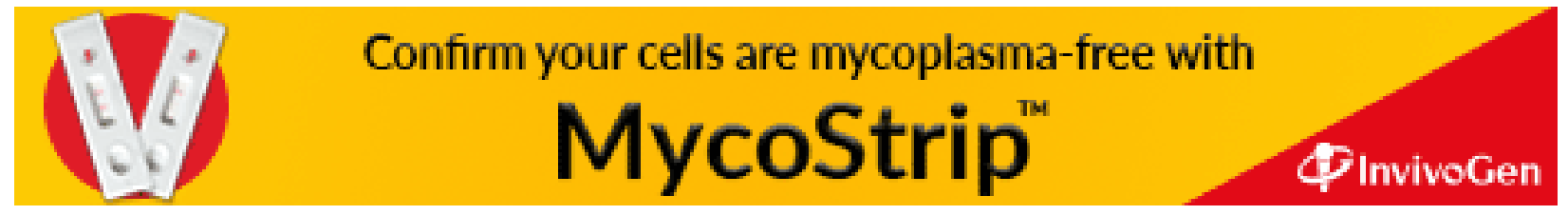

